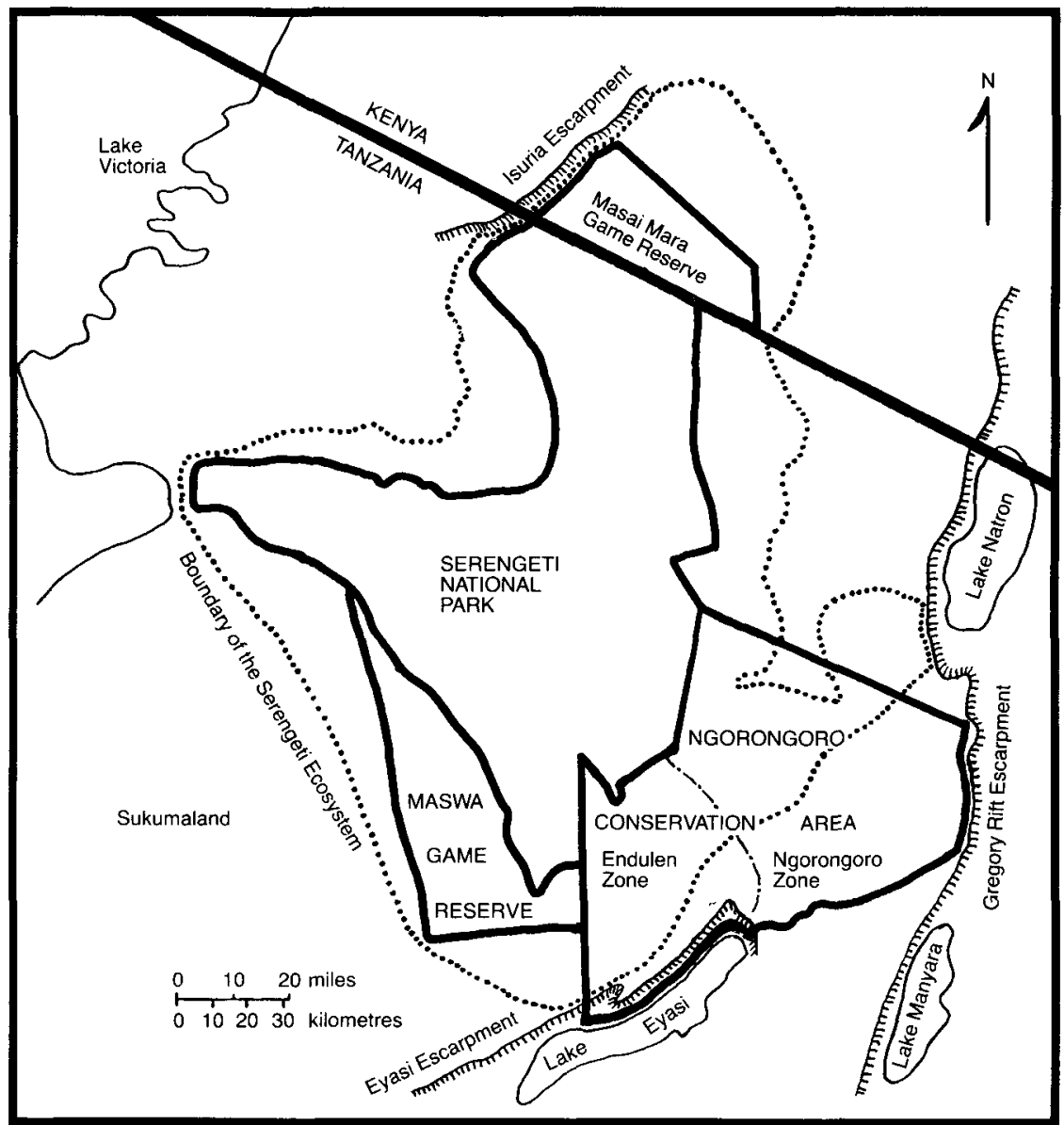

\title{
Threats to the Serengeti Herds
}

\section{Stephen Makacha, Michael J. Msingwa and George W. Frame}

The Serengeti National Park in Tanzania is famous for its huge herds of migrating wildebeest, zebras and other ungulates. But these herds spend much of the year in neighbouring reserves where their survival depends on preserving the right conditions. The authors made a study of two of these reserves with disturbing results. The Maswa Game Reserve they found was seriously threatened by invading (illegal) settlement with a fast-growing population cultivating land and felling trees; in the Ngorongoro Conservation Area they report that the Maasai have taken to poaching, both for subsistence meat and for trophies to sell - skins, ivory and rhino horn. In both places the guards are so poorly equipped they can do little to stop poaching.

The Serengeti National Park, noted for its enormous migrations of wildebeest 
and zebra, covers $12,950 \mathrm{sq} \mathrm{km}$ yet includes less than half the Serengeti ecosystem. During much of the year the migratory animals live in adjacent game reserves, controlled-hunting areas, and the Ngorongoro Conservation Area (NCA), where human settlement, cultivation, and poaching have increased over the years and law enforcement is difficult. To assess the extent of the problems in the southern part of the ecosystem, a survey was carried out in the Maswa Game Reserve (MGR) and the adjacent Endulen Zone of the NCA.

\section{Survey Area}

The whole of the Maswa Game Reserve in northern Tanzania, covering 2200 sq $\mathrm{km}$, lies within the Serengeti ecosystem; it is an important buffer zone between the southern boundary of the Serengeti National Park and the densely populated areas of Sukumaland. The northern part is mainly grassland, and the southern mainly woodland of Acacia, Combretum, Commiphora, and Brachystegia species. 4,14,16 The Serengeti wildebeest* use the reserve during part of their annual migration, ${ }^{3}$ and black rhinos are abundant. ${ }^{16}$ But villages in and around the reserve are expanding eastward, ${ }^{7,8}$ where they come into conflict with conservation measures for wildlife and water catchments. This growing human population makes the combined game reserve and national park the second most threatened ecological unit in Tanzania. ${ }^{6}$ Some of the highest rates of population increase occur on the periphery, where immigration contributes twice as many people as the net gain from births. ${ }^{8}$

The Ngorongoro Conservation Area $(8300 \mathrm{sq} \mathrm{km})$ which adjoins the Serengeti National Park and the Maswa Game Reserve, lies only partly within the Serengeti ecosystem. This is a model in multiple land-use. ${ }^{1,2,13,17}$ The habitats vary from semi-arid grassland in the west to montane cloud forest in the east, ranging from $1300 \mathrm{~m}$ to $3650 \mathrm{~m},{ }^{5}$ and the wildlife includes some of the migratory ungulates from the Serengeti. ${ }^{2,20}$ Pastoralism is one of the accepted uses of the NCA, but cultivation is forbidden. ${ }^{1,2,9}$

\section{Survey Methods}

The first two authors made two surveys, of about four weeks each, at the end of the dry season in October 1978 and October 1979. Nearly all the area was observed, either from the air or a vehicle or on foot, and the entire leading edge of cultivation in the MGR was walked from south to north. Data on settlement, cultivation, domestic animals, tree-felling, burning, and wildlife were recorded on large-scale maps. All villages were censused and residents asked for information about wild animal and domestic livestock movements. Counts of large mammals were achieved by driving and walking parallel transects cross-country, varying the distance between them according to visibility so that all the area was covered. Potential conflicts between wild and domestic animals were assessed by observing feeding habits, distribution, and body condition.

\section{Human Settlement}

The 1979 census revealed 26,358 people living in 13 villages in and near the MGR, ${ }^{14}$ which agrees very closely with the Tanzania Statistical Bureau's official census in October 1978. More than half lived in five villages inside the reserve.

The line of the MGR's western boundary is uncertain - the map shows the

\footnotetext{
* See table on p. 440 for scientific names of animals.
} 


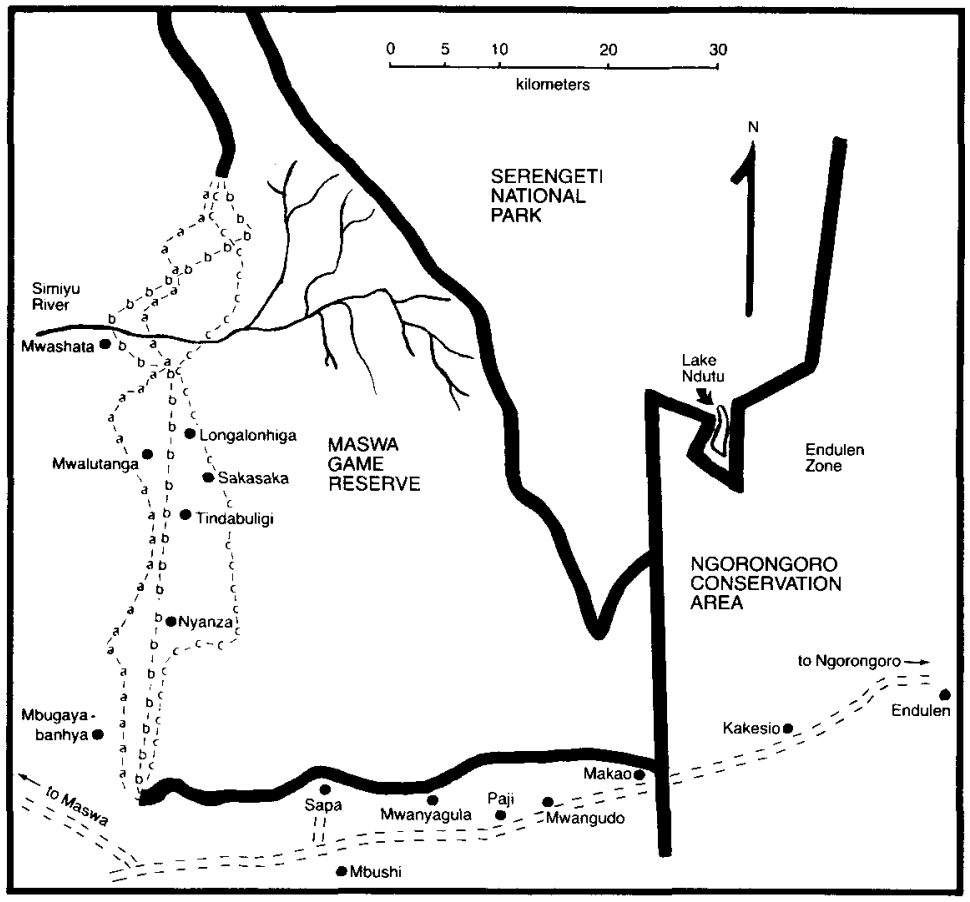

Villages within and close to the Maswa Game Reserve. $a=1962$ boundary (survey 1970), $b=1974$ boundary, $c=$ proposed 1976 boundary.

three alternatives - and this confusion plus the lack of law enforcement have allowed the uncontrolled spread of settlement into the reserve. In 1976 a boundary line was agreed by local scientists, the Maswa District Party Secretary, Development Director and a representative, and two representatives from the Regional Directorate. The Director of Game, R. Jingu, asked the Regional Development .Director to accept this, but received no reply, leaving the boundary alignment unresolved. ${ }^{12}$ Most of the area between the 1962 and the proposed 1976 boundaries is now densely settled. All the settled families in the reserve and along the western boundary are cultivating; many have livestock, and trees are cut for building materials and firewood, and to create new farmland; dry season burning destroys woody regeneration. These losses are especially serious for the resident black rhinos and the migratory wildebeest.

The encroachment problem is increasingly difficult to resolve because the villages are recognized officially. Villages throughout Tanzania are registered by the Commissioner for Ujamaa and Cooperative Development, and every regional development director is the assistant registrar for his region. A village must have at least 250 families for the District Development Committee to approve its registration. Apparently some villages were registered after they had encroached illegally into the MGR.

In the Ngorongoro Area settlement is better controlled. In 1974 cultivation was stopped in the Endulen Zone around Kakesio and Endulen villages, and in 1977 and 1978 cultivation was prohibited throughout the NCA. The people here are mainly Maasai pastoralists, with some non-Maasai shopkeepers and social and administrative workers, but both human and livestock populations are growing rapidly. ${ }^{9}$ With no cultivation allowed, the main concerns are now poaching, dry-season burning, and tree felling. 
Wild Ungulates Seen in Census Area in Early October 1979

The numbers are from total counts, and therefore represent minimum numbers present. $\mathrm{p}=$ present, $\mathrm{n}=$ not recorded.

\section{Census area}

Species

\section{Maswa Game Reserve}

\section{South of Makao village, at six waterholes}

Black rhinoceros Diceros bicornis

Buffalo Syncerus caffer

Dik-dik Madoqua kirki

Eland Taurotragus oryx

Elephant Loxodonta africana

Giraffe Giraffa camelopardalis

Greater kudu Tragelaphus strepsiceros

Impala Aepyceros melampus

Kongoni Alcelaphus buselaphus

Lesser kudu Strepsiceros imberbis

Oryx Oryx beisa

Warthog Phacochoerus aethiopicus

Wildebeest Connochaetes taurinus

Zebra Equus burchelli

Thomson's gazelle Gazella thomsoni

\section{Census area}

Endulen Zone of the Ngorongoro Conservation Area
North of
Makao and
Kakesio
villages

\author{
Lake Ndutu \\ and north and \\ west of \\ Endulen village
}

Poaching, for meat, ivory, rhino horns and skins, is difficult to control. The MGR game scouts can do little; they lack weapons, ammunition, and transport, and their three posts at Nyanza, Tindabuligi, and Kisesa (a sub-village of Sapa), are far from the reserve in cultivated areas. The NCA's nearest game scouts are at Endulen village, about $45 \mathrm{~km}$ east of the common boundary, and the headquarters at Ngorongoro village is another $32 \mathrm{~km}$ by road east of Endulen. Thus,

Locations of 45 black rhino and 20 elephant carcasses found in Maswa Game Reserve and in the Endulen Zone. The survey area is shaded. $R=$ rhino carcass, $E=$ elephant carcass.

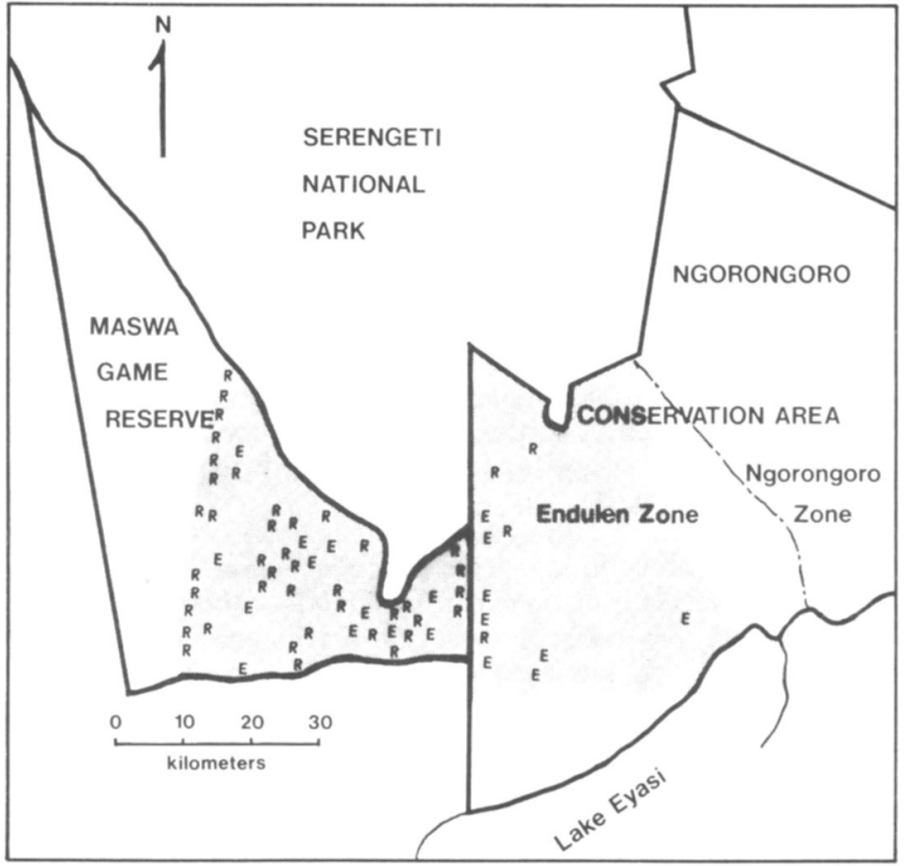




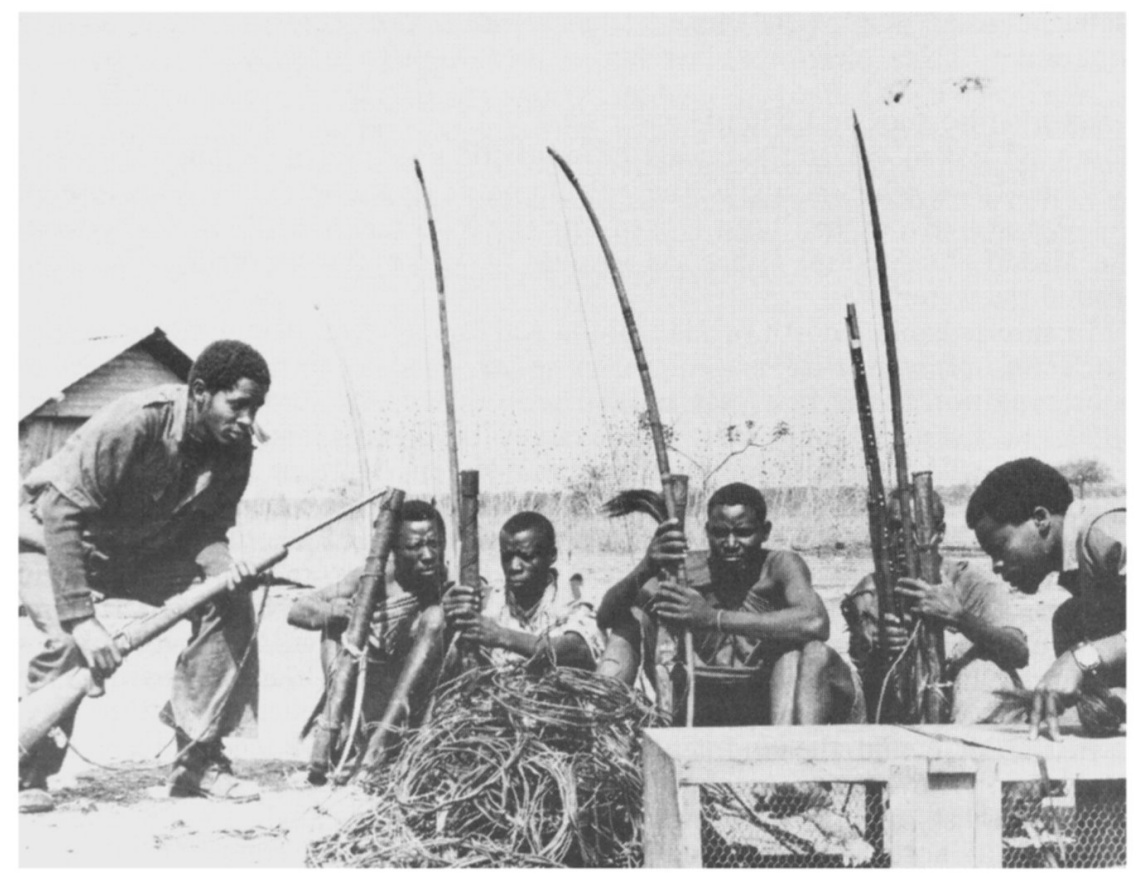

Poachers arrested in October 1979 in the Endulen Zone of the Ngorongoro Conservation Area. The cage holds Fischer's lovebirds to be sold to permit holders in Dar Es Salaam who export them to Japan, Germany, UK, USA and Canada.

poachers easily enter the MGR or cross the western boundary of the NCA.

While surveying the Endulen Zone, we twice found Maswa District residents poaching with bows and arrows, wire snares, and muzzle-loading guns. In October 1978, poachers killed eight zebra, five impala, five wildebeest, four eland, two buffalo, one giraffe, and one dik-dik. In October 1979, as well as killing five zebra, three giraffe, two eland, one buffalo, and one dik-dik, they had 60 live Fischer's lovebirds Agapornis fischeri in cages. Four men were arrested in each incident, taken to court, and convicted, each receiving four years imprisonment and a fine of Tsh 1600 . During the surıays, 41 black rhino and 12 elephant carcasses were found in the eastern half of the MGR, and carcasses of four black rhinos and eight elephants were found in the Endulen Zone. Most showed signs of poaching, but it was impossible to determine the cause of death in every case.

In 1977-79, 49 poachers were arrested in the MGR and 210 arrested for poaching and other offences in the NCA. ${ }^{12,13}$ Everyone arrested admitted guilt and paid a fine, or was later tried by the courts, and found guilty. The fewer arrests in the MGR is due to the scouts' almost total lack of support and equipment.

The traditional attitude of the Maasai to hunting seems to be changing. In the past the warriors occasionally speared elephants and black rhinos to prove their bravery. ${ }^{2}$ Now economic incentives apparently induce them to try to sell 
elephant tusks and black rhino horns, ${ }^{10,11}$ and their deteriorating economic situation probably means that poaching will continue to increase. ${ }^{15}$

\section{Domestic Livestock and Wildlife}

South of Makao village there were no domestic livestock in October 1978 and October 1979, when normally they would be using the waterholes, because all the Maasai livestock had been moved into the NCA due to cattle thefts between the Maasai and Sukuma tribes. As a result 14 wild herbivore species were seen around the waterholes.

In similar habitat north of Makao and Kakesio villages, where domestic livestock were present at the end of the dry season in both years, cattle appeared in poor condition in the first year and worse in the second. Between 1-8 October 1979, the livestock count was: 9214 cattle, 7416 goats, and 5003 sheep. Ten species of wild herbivore were also present but at this time of year the huge migratory herds of wildebeest and zebras are away to the west and north. ${ }^{20}$

The area around Lake Ndutu and north and west of Endulen village is an important habitat for wild ungulates in the dry season, and for wildebeest in the wet season. ${ }^{16}$ At the end of the 1978 and 1979 dry seasons there was abundant good quality forage in the unburnt areas, where ten wild herbivore species were seen, but little use by domestic livestock. Results of the total count made in October 1979 are given in the table.

In the MGR and the Endulen Zone in both years, there seemed to be little competition for grazing in the dry seasons. Wildlife moved locally to avoid the pastoralists and their livestock. The forage was adequate for the animals present, but north of Makao and Kakesio villages the poor condition of cattle, wildebeest, and Thomson's gazelles showed that local inadequacies occur. Water was sufficient, and apart from isolated instances of elephants destroying earthen cattle troughs and filling in wells, there was minimal conflict. Forage was depleted before water became limiting. The Maasai tend to keep their cattle near permanent water, even after pastures elsewhere have revived with the rains, partly to avoid the risk of disease from wildlife, and partly because of the lack of suitable alternative water.

\section{Conclusions and Recommendations}

The uncertainty about the alignment of the western boundary of the MGR provides a legal loophole for settlement. But the reserve is so important for the Serengeti migrations and the threatened black rhino that every effort should be made to stop further land losses. The 1976 boundary change proposed by the Director of Game represents a reasonable compromise between the Game Division and the village development authorities; it would minimize the expenses and hardships of resettlement, and guarantee that there will be no further loss of wildlife habitat and watershed. It should be accepted and gazetted to avoid future possible disputes. Once it is agreed, both the new legal boundary along the western side of the MGR and the southern boundary should be surveyed, cleared, ploughed, and reset with beacons.

To combat the poaching, Tanzanian authorities should request financial assistance from international conservation agencies for anti-poaching patrols in the MGR and Endulen Zone, and the game-scout posts should be moved closer to the poached areas. Village butcher shops providing cattle, sheep, and goat meat at reasonable cost would eliminate the need for subsistence poaching. The 
present and future value of the Serengeti ecosystem's flora and fauna, in terms of national heritage, ${ }^{8}$ watershed, ${ }^{13}$ tourist income, ${ }^{19}$ and meat production through cropping, far exceeds any short-term benefits to be gained by increasing domestic livestock numbers or allowing unplanned settlement and poaching. Tanzania recognizes this and has made substantial progress since independence. The new conservation laws and better enforcement should ensure the conservation of wildlife and natural resources for the benefit of all if the rapidly increasing human population and its demands on resources can be contained. ${ }^{18}$

\section{Postscript}

In 1981 substantial progress was made in stopping further settlement and reducing poaching in the MGR. With funds donated by the Frankfurt Zoological Society, game department employees were able to clear and reset beacons along half the disputed boundary before heavy rains in April forced them to stop, but since then work has resumed. The new boundary follows the 1976 proposed boundary, with minor adjustments to avoid houses and farms. ${ }^{21}$ Poachers have been arrested and fined, and some received 6-month prison sentences. To improve public relations, the game reserve personnel have explained the reasons for the new boundary demarcation to villagers, and encouraged some of them to resettle in villages further from the reserve.

Efforts at resolving these threats to the MGR have been prompt and effective. However, considerable work remains to be done, and continued international financial support is essential.

\section{Acknowledgments}

We thank the former Chief Conservator, A. N.J. Mgina, and the Principal Assistant Conservator, P. ole Sayalel, of the NCA Authority for requesting this survey. Stephen Makacha's field-work was financially supported by the African Wildlife Leadership Foundation. Assistance in the field-work was given by Sabastian Chuwa, Stephen Lelo, Robert Raphael, Ernest Manase (all of the NCA Authority Staff), and by Paschal N. Makang'a, Modest Mworio, Nyasibu Sai, Selestin Sadala, Samla Makondo (all of the Game Division Staff). Typing was by Mrs Quenie Mwakyusa at the District Game headquarters, Maswa. For providing helpful comments on earlier versions of this manuscript, we thank: A.N.J. Mgina; R.D. Estes, R.B.M. Senzota and F. Kurji of the Serengeti Research Institute; S. Price, Director of Operations, African Wildlife Leadership Foundation, Nairobi; and D. J. Herlocker, UNESCO Regional Office, Nairobi.

This is Serengeti Research Institute contribution No. 308.

\section{References}

1. DIRSCHL, H.J. 1966. Management and development plan for the Ngorongoro Conservation Area. Ministry of Agriculture, Forests, and Wildlife, Dar es Salaam. 142pp. +2 appendices +1 table +4 maps.

2. FOSBROOKE, H. 1972. Ngorongoro: The eighth wonder. André Deutsch, London. 240pp. + plates.

3. GRZIMEK, M. and B. GRZIMEK. 1960. A study of the game of the Serengeti Plains. Zeitschrift für Säugetierkunde 25: 1-61+2 maps.

4. HERLOCKER, D.J. 1975. Woody vegetation of the Serengeti National Park. Texas A\&M University, College Station, Texas. 39 pp. + map.

5. HERLOCKER, D.J. and H.J. DIRSCHL. 1972. Vegetation of the Ngorongoro Conservation Area, Tanzania. Canadian Wildl. Serv. Rpt. Ser. No. 19. Information Canada, Ottawa, Ontario. 39pp. + map.

6. KURJI, F. 1976. Conservation areas and their demographic settings in 
Tanzania. BRALUP Res. Rpt. No. 18 (New Series). University of Dar es Salaam, Dar es Salaam.

7. KURJI, F. 1976. Settlement development and the Maswa Game Reserve. Internal report. Serengeti Research Institute, Seronera, Tanzania.

8. KURJI, F. 1979. Human population densities and their changes around the major conservation areas of Tanzania. BRALUP Res. Rpt. No. 51 (New Series). University of Dar es Salaam, Dar es Salaam.

9. MAKACHA, S. and G.W. FRAME. 1979. Human and domestic livestock censuses in the Ngorongoro Conservation Area, Tanzania, and resulting management recommendations. Ngorongoro Conservation Area Authority, Ngorongoro Crater, Tanzania. 22pp.

10. MAKACHA, S., C.L. MOLLEL, and J. RWEZAURA. 1979. The conservation status of the black rhinoceros (Diceros bicornis, L.) in the Ngorongoro Crater, Tanzania. African Journal of Ecology 17: 97-103.

11. MAKACHA, S. and C.L. MOLLEL. 1979. Factors affecting the distribution of rhinos in the Ngorongoro Conservation Area Authority, Tanzania. Ngorongoro Conservation Area Authority, Ngorongoro Crater, Tanzania.

12. MAKACHA, S., M.J. MSINGWA, and G.W. FRAME. 1980. Conservation problems in the Endulen Zone (Ngorongoro Conservation Area) and Maswa Game Reserve, Tanzania. Ngorongoro Conservation Area Authority, Ngorongoro Crater, Tanzania. 24pp.

13. MAKACHA, S., J. RWEZAURA, and G.W. FRAME. 1980. Law enforcement in Ngorongoro. Swara 3 (5): 25-27.

14. MAKACHA, S., M.J. MSINGWA, and G.W. FRAME. 1981. A survey of settlement, poaching, wildlife, and pastoralism in the Maswa Game Reserve and in the Endulen Zone of the Ngorongoro Conservation Area, Tanzania. Ngorongoro Conservation Area Authority, Ngorongoro Crater, Tanzania. $24 \mathrm{pp}$.

15. MGINA, A.N.J. 1979. What does the future hold for Ngorongoro Conservation Area? Ngorongoro Conservation Area Authority, Ngorongoro Crater, Tanzania.

16. NORTON-GRIFFITHS, M. 1972. Serengeti Ecological Monitoring Program. African Wildlife Leadership Foundation, Washington, D.C. 20036. 25 pp.

17. ole SAIBULL, S.A. 1968. Ngorongoro Conservation Area. East African Agricultural and Forestry Journal 33 (Special Issue): 11-18.

18. ole SAIBULL, S.A. 1978. The policy process: The case of conservation in the Ngorongoro Crater highlands. Tanzania Notes \& Records No. 83: 101115

19. RODGERS, A.W. and B.D. NICHOLSON. 1973. Guidelines for long-term development of selected game areas with suggested management and development plans. Ministry of Natural Resources and Tourism (Game Division Natural Projects), Dar es Salaam. $51 \mathrm{pp}$.

20. SINCLAIR, A.R.E. and M. NORTON-GRIFFITHS 1979. Serengeti: Dynamics of an ecosystem. University of Chicago Press, Chicago. 389pp.

21. MAKACHA, S., M.Y.S. KWAGILWA, and S.R. SELESTINE 1981. Demarcation of Maswa Game Reserve boundary (Shinyanga Regional Directorate; Tanzania). Ngorongoro Conservation Area Authority, Ngorongoro Crater, Tanzania. $14 \mathrm{pp}$.

Stephen Makacha, Ngorongoro Conservation Area Authority, P.O. Box 1, Ngorongoro Crater, Tanzania (Present address: College of African Wildlife Management, Mweka, P.O. Box 3031, Moshi, Tanzania); Michael J. Msingwa, Maswa Game Reserve, P.O. Box 149, Maswa, Tanzania; George W. Frame, Serengeti Research Institute, P.O. Seronera, via Arusha, Tanzania (Present address: Dept. of Fisheries and Wildlife, College of Natural Resources, Utah State University, Logan, Utah 84322, USA). 